\title{
Effects of pressure ridge sheltering on the spatial and temporal variability of boundary layer stability under first year sea ice
}

\author{
Éric HUDIER $^{\text {a* }}$, Grant INGRAM ${ }^{\text {b }}$ \\ ${ }^{a}$ Département d'océanographie, Centre océanographique de Rimouski, université du Québec, 310, allée des Ursulines, \\ Rimouski, Québec, G5L 3A1, Canada \\ ${ }^{b}$ Department of Atmospheric and Oceanic Sciences, McGill University, 805 Sherbrooke St. W., Montréal, Québec, H3A \\ 2K6, Canada
}

(Received 10 December 1998, revised 15 April 1999, accepted 27 May 1999)

\begin{abstract}
$\Lambda$ bstract - We present series of data describing the small-scale structure of the boundary layer stratification in the vicinity and away from a $1.5 \mathrm{~m}$ pressure ridge keel. We then analyze the influence of pressure ridges on the spatial and temporal variability of the ocean boundary layer. Our experiment was done during the melt in order to use small-scale salinity gradients to study the variability in intensity of mixing processes. High-resolution salinity records sampled at $0+, 25$ and $50 \mathrm{~cm}$ from the ice-water interface were analyzed at two stations, one at $5 \mathrm{~m}$ and the other at $75 \mathrm{~m}$ from a pressure ridge keel. We observed that, in the immediate vicinity of the ridge, melting is associated with the periodic development and dissipation of a melt layer in relation with the orientation of tidal currents relative to the ridge. In contrast, away from the region under the sheltering influence of the ridge keel, the boundary layer did not show any evidence of stratification during the whole experiment. Data recorded in the vicinity of the ridge are then used to compute eddy diffusivity coefficients for sheltered and non-sheltered events. The observation of a stable melt layer in the vicinity of a ridge keel confirms that pressure ridges drastically modify the dynamics of vertical exchanges in their wake. Besides, our data show a significant spatial and temporal eddy diffusivity variability with a factor 10 between sheltered and non-sheltered areas. Thus, considering that ridges and rubble fields form a substantial fraction of ice-covered areas, our results suggest that effects in their wake may be important in the global budget of ocean-ice exchanges. (C) 1999 Ifremer / CNRS / IRD / Éditions scientifiques et médicales Elsevier SAS
\end{abstract}

\section{ice / roughness / boundary layer / eddy diffusivity}

Résumé - Influence des crêtes de pression sur la variabilité spatiale et temporelle de la stabilité de la couche limite sous une glace de première année. Cette recherche présente un ensemble de données acquises sur un cycle mortes-eaux, vives-eaux simultanément dans le sillage d'une crête de pression et hors de la zone d'influence de celle-ci. Ces données sont ensuite exploitées dans le but d'analyser l'influence des crêtes de pression sur la variabilité spatiale et temporelle de la stabilité de la couche limite sous une glace de première année. Les mesures de terrain furent réalisées en période de fonte alors que le développement de faibles gradients verticaux de salinité permet d'étudier l'intensité des processus de mélange. Trois sondes de salinité haute résolution furent installées à $0+, 25$ et $50 \mathrm{~cm}$ de l'interface en deux stations l'une à $5 \mathrm{~m}$ d'une crête de pression et l'autre à $75 \mathrm{~m}$. Il fut observé qu'au voisinage de la crête, la fonte est associée à un cycle développement dissipation d'une couche d'eau saumâtre en relation avec l'orientation du courant de marée par rapport à l'axe de la crête. En parallèle, nos mesures hors de la zone d'influence de la crête montrent une couche limite bien mélangée tout au long de la période d'échantillonnage. Ces données sont ensuite exploitées pour déterminer les coefficients de diffusion turbulente

* Correspondence and reprints 
en zone abritée et non abritée. L'observation d'une couche d'eau de fonte stable à proximité d'une crête confirme que les crêtes de pression modifient de façon sensible la dynamique des échanges verticaux dans leur sillage. En outre, nos données montrent une variabilité spatiale et temporelle significative du coefficient de diffusion turbulente avec un facteur minimum de 10 entre zones abritée et non abritée. En conséquence, considérant que les crêtes forment une fraction substantielle du couvert de glace, nos résultats suggèrent que les effets dans leur sillage pourraient être importants pour le calcul du bilan global des échanges océan-glace-atmosphère. (1) 1999 Ifremer / CNRS / IRD / Éditions scientifiques et médicales Elsevier SAS

\section{glace / rugosité / couche limite / diffusion turbulente}

\section{INTRODUCTION}

In coastal areas, where landfast ice forms, weather and ocean conditions produce a wide range of under-ice structures from millimeters to meters in the vertical dimension and from meters to hundreds of meters in terms of horizontal spacing. The velocity distribution near roughness elements is complex. Chriss and Caldwcll [2], showed that multiple roughness scales can generate velocity profiles with more than one typical friction velocity. Beyond a distance of 10 to 15 times the roughness element height [1] an internal boundary layer begins to form in equilibrium with the smoother surface above.

Increased eddy diffusion enhances vertical heat, salt exchanges and therefore melt rates $[9,11,23]$. It follows that melt rates are dependent on the height and spacing of ridge keels $[14,17]$ and should be variable with distance to the closest ridge upstream $[1,6]$. Stcele ct al. [16], Rahm and Svensson [15] and Svensson and Omstedt [17] have discussed the influence of the molecular sublayer on melt rates. When mixing is reduced, a buoyant meltwater layer may develop insulating the ice interface, therefore reducing the melt. When mixing is more intense, the molecular sublayer is thinner and melt rates higher. It is expected that both these conditions would be observed on the underside of the ice depending on ridge distribution and current orientation.

However, most models represent the ice-water interface as a surface of uniform roughness $[12,13,16]$ or with roughness elements sparsely distributed within the boundary layer $[14,17]$; representations which do not consider the blockage effect. If we consider that pressure ridges form a network with densities ranging from 0.5 up to 6.8 ridges per $\mathrm{km}[3,4,7,20,21,22]$, areas under the sheltering influence or the wake effect behind ridges may be of major importance when calculating melt fluxes, heat budgets or algae production. This research aims at understanding the characteristics of the boundary layer at the ice-water inter- face of a flat ice floe as a function of the ridge distance in order to determine whether individual ridges create a spatial variability in ocean-ice exchange processes.

In early summer, the increase in solar radiation modifies the thermodynamic equilibrium of sea ice [10]. The upward heat loss towards the atmosphere decreases leading to an increase in the ice temperature, a melt of brine channels and pockets walls and a decrease in the upward conductive flux $[3,8]$. On the underside of the ice, when the water-to-ice heat flux exceeds the upward conductive flux through the ice, the bottom ice starts to melt [11].

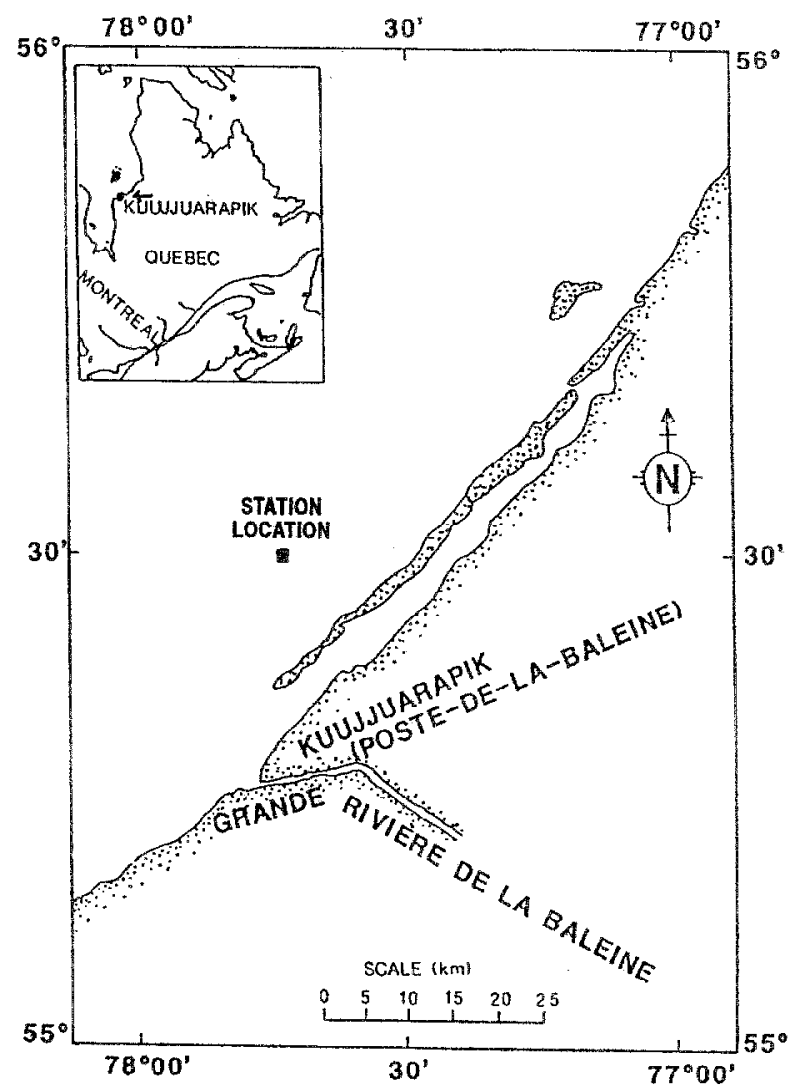

Figure 1. Map of sampling area. 
This period, the initiation of the melt, is particularly interesting when looking at the spatial variability of the boundary layer structure. The transition from freezing (well mixed conditions) to melting induces the production of weak buoyancy whose effect should be uneven if the boundary layer dlemonstrates a spatial variability.

\section{MATERIAL AND METHODS}

Our sampling stations were located on a large unbroken ice floe about $24 \mathrm{~km}$ offshore of the Great Whale River mouth, on the outer rim of the large brackish plume formed under a nearly continuous landfast first-year sea ice cover (figure 1). Conductivity and temperature variations were recorded at two stations, one close to a pres. sure ridge keel (station $\mathrm{R}$ ) and another away from ridge influence in the direction of the center of the ice plate (station P) (figure 2). CTD profiles were taken periodically at eight locations, one and two kilometers north, east, south and west of station P. These profiles were done at low tide within a period of about one hour in order to have a picture of horizontal surface gradients. A west-east horizontal gradient of about $0.1 \mathrm{~km}$ was

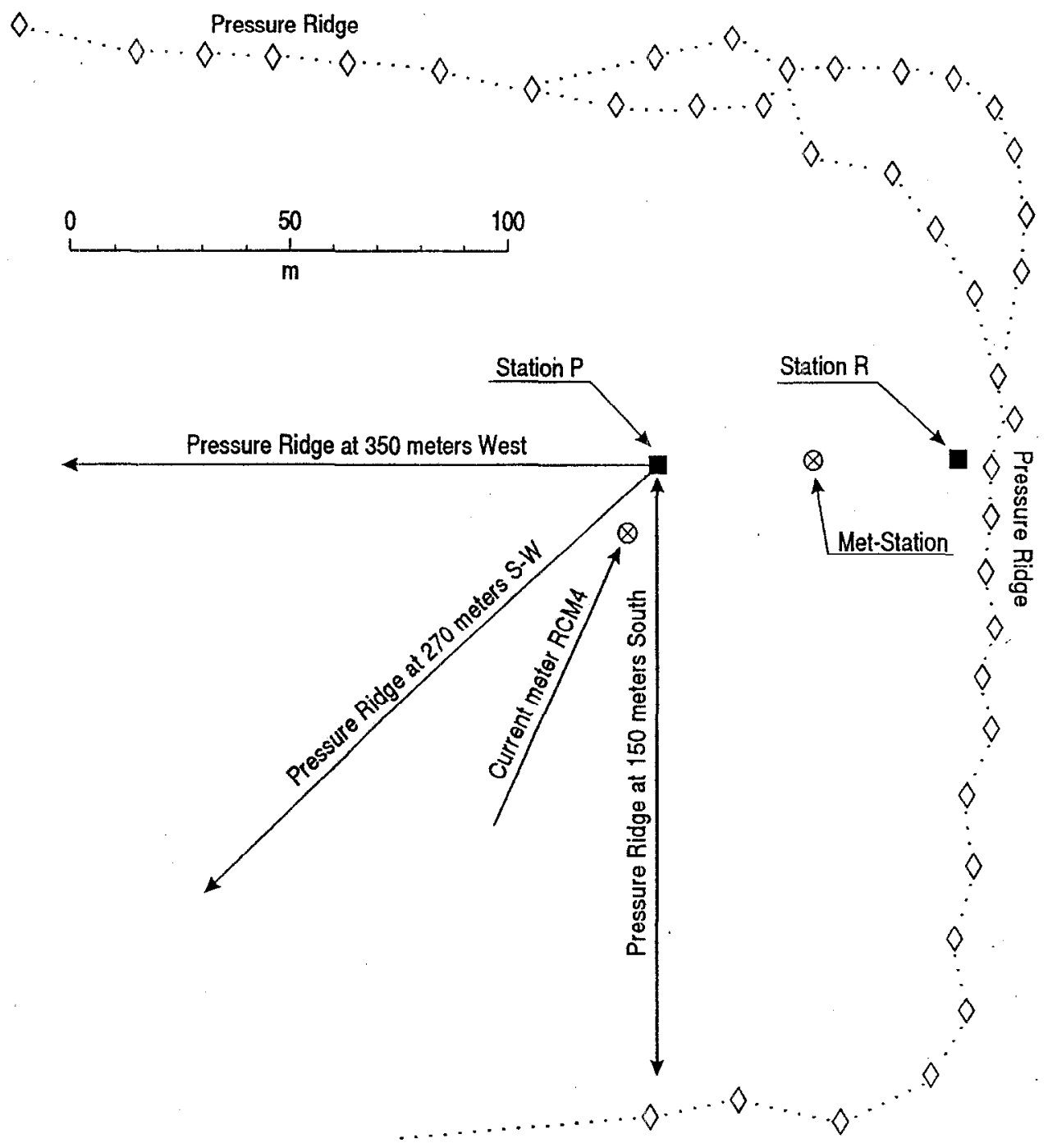

Figure 2. Installation of sampling equipment at two stations located at 5 and $75 \mathrm{~m}$ from a pressure ridge. The met-station and the three icetemperature probes were installed at mid-distance between the two stations. Ice thickness was $1.16 \mathrm{~m}$ close to the ridge and $1.40 \mathrm{~m}$ at the metstation and station P. 
observed throughout the experiment whereas no significant north-south gradient was measured.

The maximum sail height of the pressure ridge in the inmediate vicinity of station $R$ was between $1 \mathrm{~m}$ and $1.25 \mathrm{~m}$ with individual block thickness of $33 \mathrm{~cm}$. It shows that the ridge was formed at the beginning of winter enabling ice growth to seal the fracture zone and prevent meltwater leaks which could have affected our data. Based on an evaluation of the ice volume in the ridge sail, average keel height and width of about 2.5 and $5 \mathrm{~m}$ can be assumed at the time the ridge was formed. Taking into account ice growth, a reasonable evaluation gives a ridge keel height of about $1.50 \mathrm{~m}$. While inspecting micro-TS probes, installation divers observed that they were fixed on flat ice about $2 \mathrm{~m}$ from the first ice blocks. They also described an irregular ridge ranging from half a man's size to about the height of a diver. Ice thickness was $1.40 \mathrm{~m}$ at station $\mathrm{P}$ and at the met-station location and $116 \mathrm{~cm}$ at station $\mathrm{R}$.

Surface meteorological data at $10 \mathrm{~m}$ above the ice level and ice temperatures at depths of 25,70 and $115 \mathrm{~cm}$ below the snow-ice interface were recorded every $30 \mathrm{~min}$ using an Aanderaa met-Station and temperature sensors (model 1289) installed at mid-distance between stations $P$ and $\mathrm{R}$ (figure 3). Temperature sensors were implanted three days prior to the first measurement through $5 \mathrm{~mm}$ drilled holes, and the snow layer restored.

From 21 April to 5 May, 1990, data were recorded every minute at $0+, 25$ and $50 \mathrm{~cm}$ from the ice-water interface using Applied Microsystems mini-probes at station $\mathrm{P}$ and at $0+$ and $25 \mathrm{~cm}$ from the interface using small Aanderaa S-T Sensors (model \#3211) at station $\mathrm{R}$. The $0+$ position identifies the sensor installed at the interface with one of its sides in contact with the ice. Considering the position of the cell's center as reference point, in computations this probe will be assumed at $1 \mathrm{~cm}$ from the ice interface. As a point of reference, salinity, current speed and direction were recorded at $2.5 \mathrm{~m}$ by an Aanderaa RCM4 installed at station P. Sensors were calibrated in the laboratory before and after the field work. In addition, at the beginning of the experiment, all sensors (except those on the Aanderaa current meter) were placed in the same well-mixed flow and the outputs measured. The measured precision on the zero salinity gradient was 0.02 at station $\mathrm{P}$ and 0.035 at station $R$.

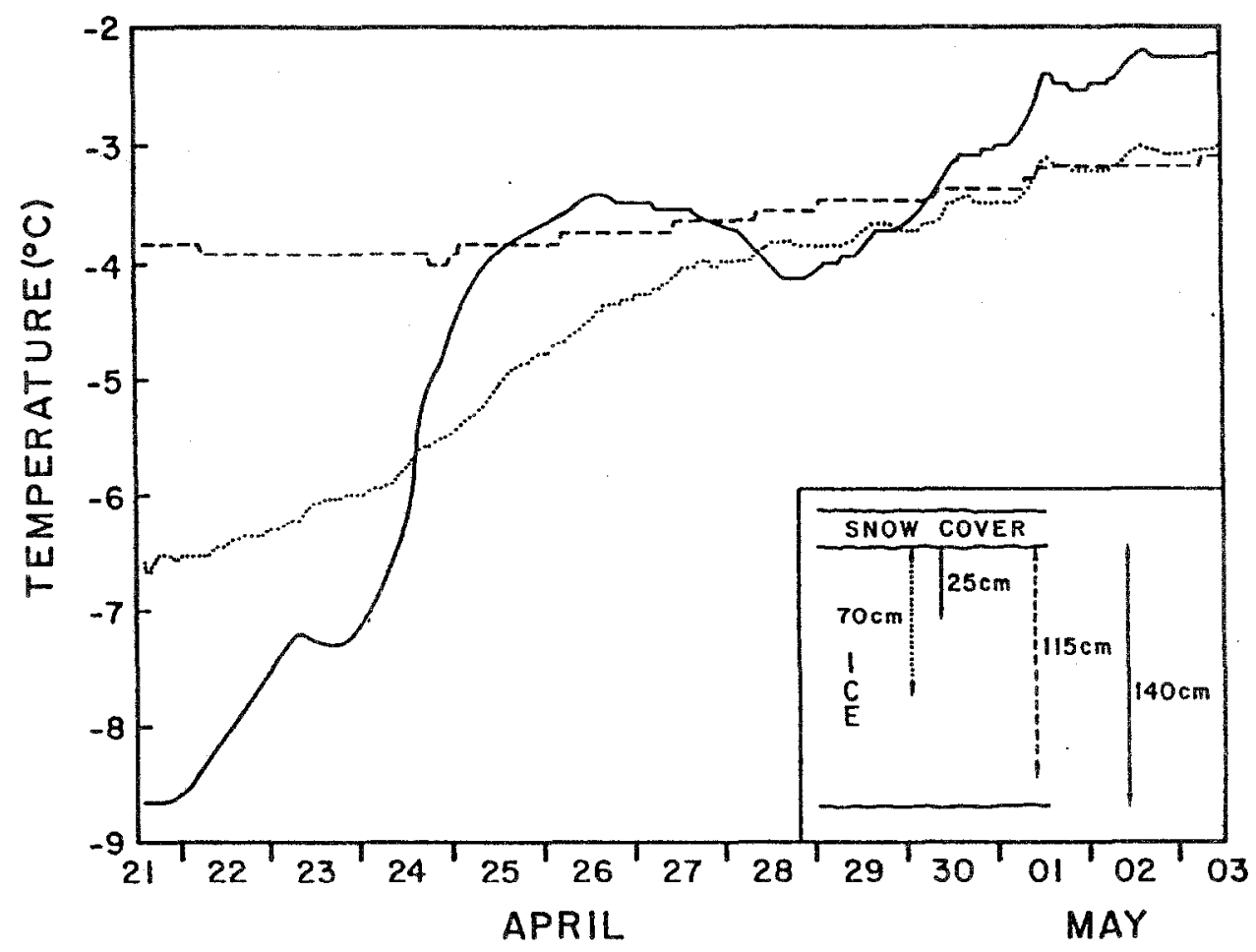

Figure 3. Temperature of the ice at three depths from the ice-snow interface: $25 \mathrm{~cm}$ (solid line), $70 \mathrm{~cm}$ (dotted line) and $115 \mathrm{~cm}$ (dashed line). 


\section{RESULTS AND DISCUSSION}

The 12-day salinity time series shows a slow increase of the surface water salinity (figure $4 \mathrm{a}, 4 \mathrm{~b}$ ). This could indicate either a vertical diffusion from the saltier underlying water or a horizontal shift of the Great Whale River plume. However, temperature profiles (figure 5) show a decrease of the surface layer temperature. As the intermediate water layer (20-40 $\mathrm{m}$ deep) was warmer than the surface water layer (figure 4), vertical mixing in the upper $40 \mathrm{~m}$ would have produced an increase in the surface layer temperature. This suggests that the salinity increase was caused by a change of the river plume orientation similar to that observed by Ingram and Larouche [5].
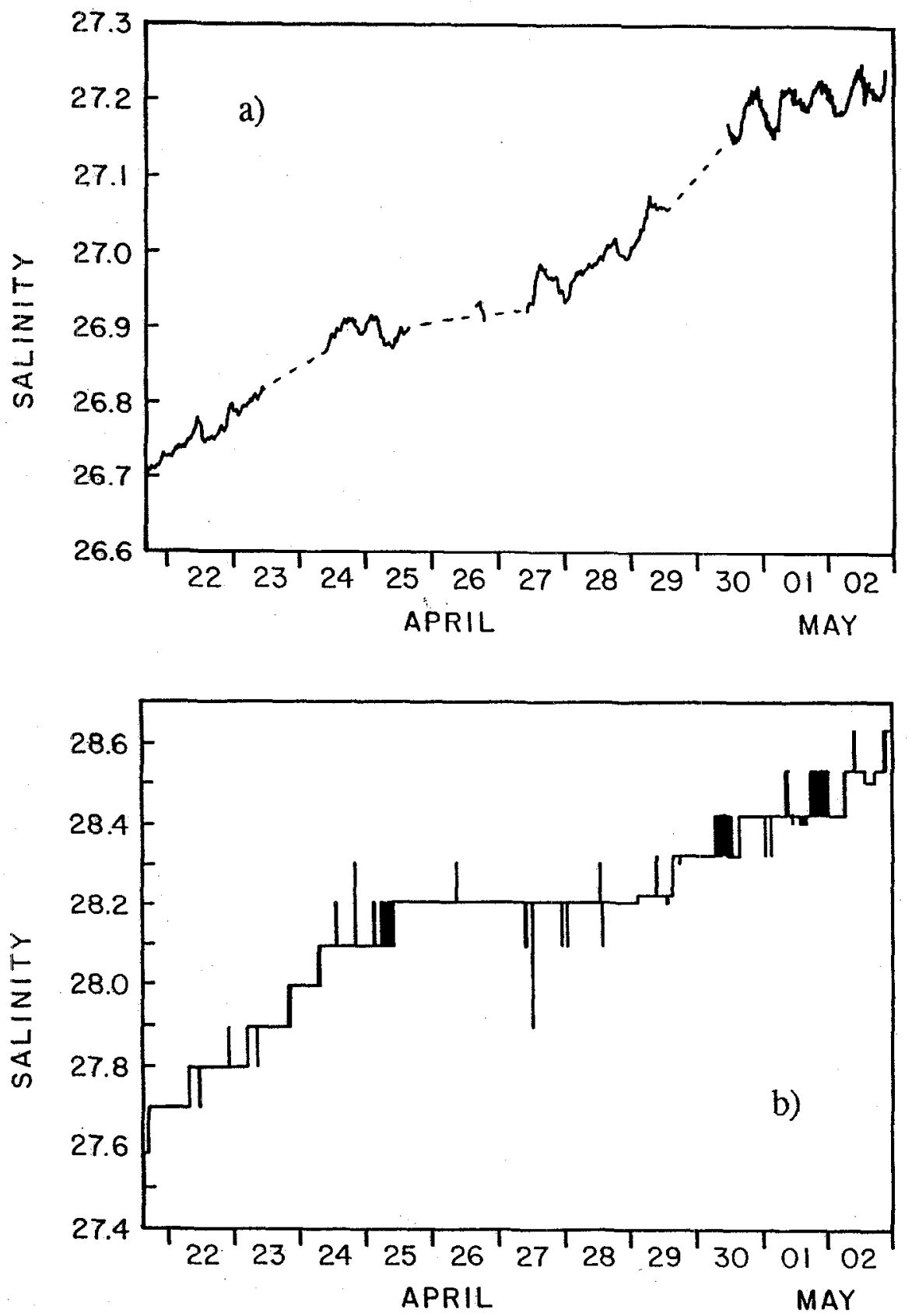

Figure 4. Time series records of salinity from a 10 -min moving average: a) at station $P, 25 \mathrm{~cm}$ from the ice interface (accuracy 0.025 ), b) at $2.5 \mathrm{~m}$ from the ice interface (digitalization interval 0.1). Dashed lines indicate missing data. 
In addition, CTD profiles show a consistent surface horizontal gradient (measured at $0.5 \mathrm{~m}$ below the ice) of about $0.1 \mathrm{~km}^{-1}$ in the W-E direction which, coupled with an averaged surface water shift of $550 \mathrm{~m} \mathrm{NW}$ per day, explains the gradual increase of salinity. The surface water shift was computed from current measured at $2.5 \mathrm{~m}$ below the ice from 22 April to 24 April and 30 April to 2 May. Also from 25 April through 29 April weak neap tide currents, below the Aanderaa threshold velocity, were measured explaining the salinity stability during this period (figure $4 \mathrm{~b}$ ).

Increased salinity has only a very small effect on melt rates and thus will not be considered in the discussion. A rough evaluation using the molecular sublayer approach of Svensson and Omstedt [17] reveals that an increase of 0.5 (the full range during the experiment), would enhance the melt rate by about $0.125 \mathrm{~cm} \mathrm{day}^{-1}$ which is a very small effect.

\subsection{Sea ice response to the spring solar irradiance increase}

In the second half of the experiment, salinity time series show cyclic fluctuations (figure 6) associated, at station $\mathrm{R}$, with the development of a significant vertical gradient (figures 7, 8). This gradient, calculated as the difference of the salinity at $25 \mathrm{~cm}$ minus the salinity at $1 \mathrm{~cm}$ below the ice-water interface, demonstrates the development of a melt layer on the underside of the ice in the immediate vicinity of the pressure ridge. These data suggest that the start of the melt induced by the spring solar

\section{TEMPERATURE $\left({ }^{\circ} \mathrm{C}\right)$}

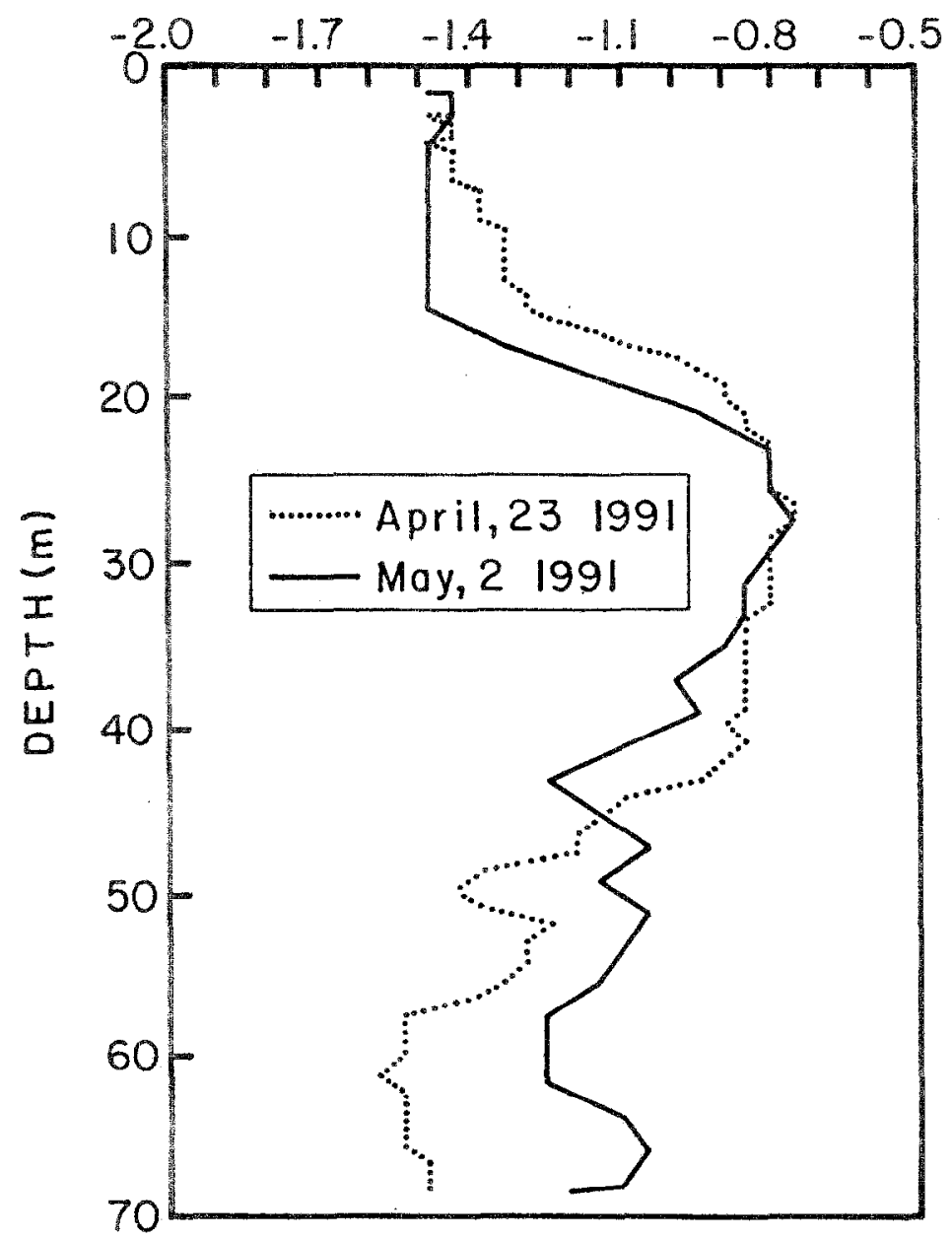

Figure 5. Temperature profile from S4 InterOcean current meter recordings. The decrease of the surface layer temperature points out a plume shift. 
irradiance increase is sudden. Ice temperature data rccordcd at three lcvels inside the ice reveal that the initiation of the melt started when the ice was almost isothermal (figure 3). In addition, it was observed that the snow layer became saturated with meltwater on 29 April and that pools of meltwater started to form on 30 April. In the model of Maykut and Untersteiner [8], a sudden increase in ice temperature was shown to follow isothermal conditions. They stated that "when snow is salurated with meltwater, no heat flows toward the surface...". These results suggest that the existence of a snow layer saturated with meltwater could be associated with the initiation of the melt of the underside of the ice with a lag of less than a day.
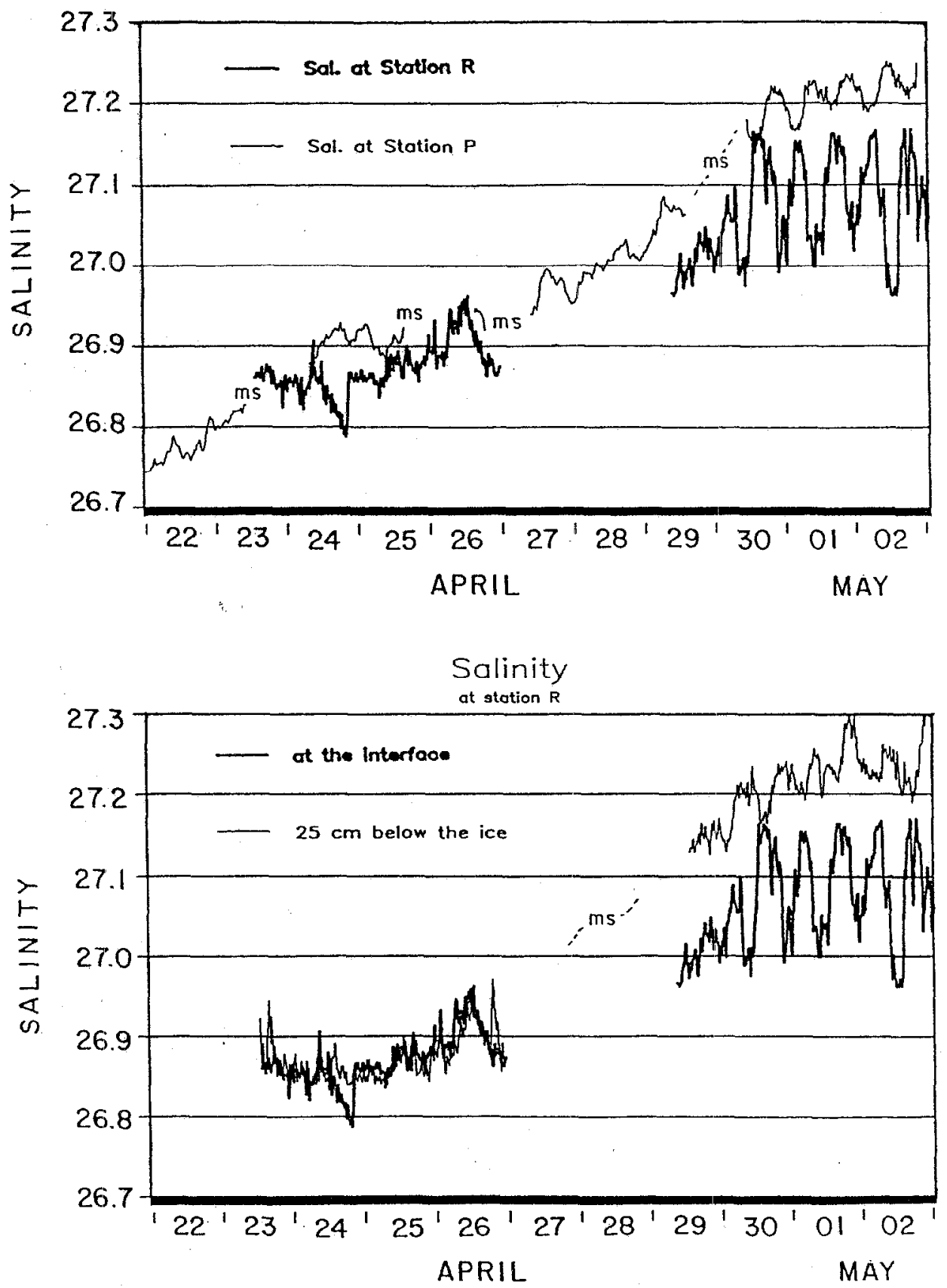

Figure 6. Salinity time series from a $2-\mathrm{h}$ moving average calculated from: a) data recorded at the interface at station $\mathrm{P}$ and station $\mathrm{R}$; b) data recorded at the interface and at $25 \mathrm{~cm}$ below the interface at station $\mathrm{R}$ [ms indicates missing data]. 
At station $P$, weak salinity fluctuations recorded at the interface in phase with current speed variations suggest an uptake of meltwater starting 1 May at 20:00. At this time, salinity pulses, previously salt water pulses, became weak but significant $(0.005)$ fresh water pulses. The lag in the occurrence of a meltwater flux between the two stations may be a consequence of the difference in ice thickness, $1.40 \mathrm{~m}$ at $\mathrm{P}$ compared to $1.16 \mathrm{~m}$ at $\mathrm{R}$.

\subsection{Spatial variability of the upper boundary layer structure}

At station $\mathrm{P}$, the main salinity fluctuations were identical on all three sensors and were in phase with those observed at $25 \mathrm{~cm}$ from the interface at station R. Figure 7 presents a plan view of the mean current during four tidal cycles beginning on 30 April at 18:00 (figure 7a) with the corresponding response of the salinity time series (figure $7 \mathrm{~b}$ ). It reveals two distinct phases with a first phase, the salinity increase, occurring while currents were directed towards the center of the floe (roughly westward) and a second phase, the salinity decrease, while currents were oriented towards the ridge (roughly eastward). These results are consistent with the horizontal salinity gradient observed west-east and show that these fluctuations are mainly due to the upstream salinity distribution.

Near the pressure ridge, at station $\mathrm{R}$, we observe a different pattern with salinity fluctuations in opposition of

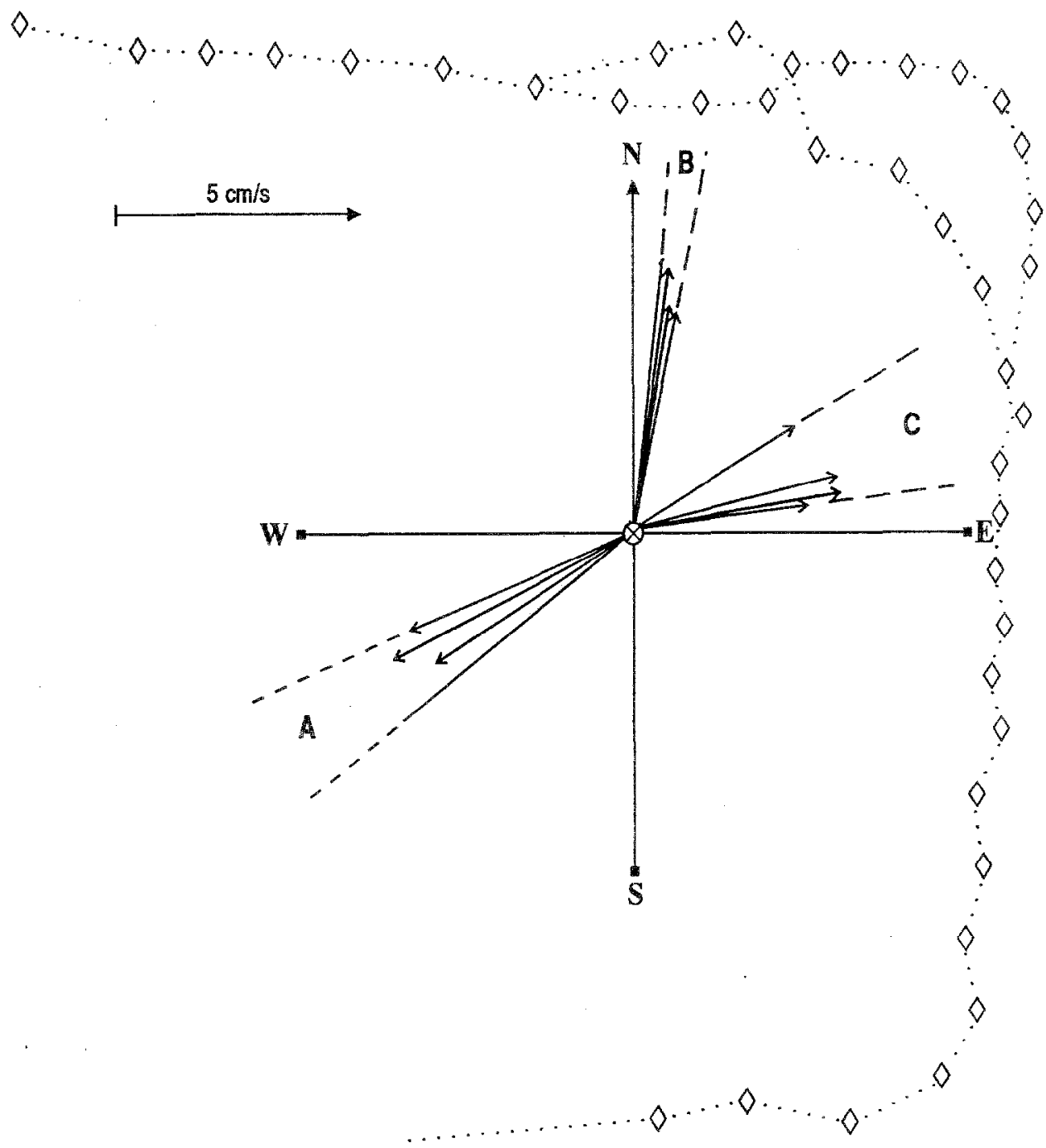

Figure 7a. Plan view of mean tidal currents for each of the four tidal cycles during which salinity fluctuations (figure $7 \mathrm{~b}$ ) were measured at the interface, at station $\mathrm{R}$. 


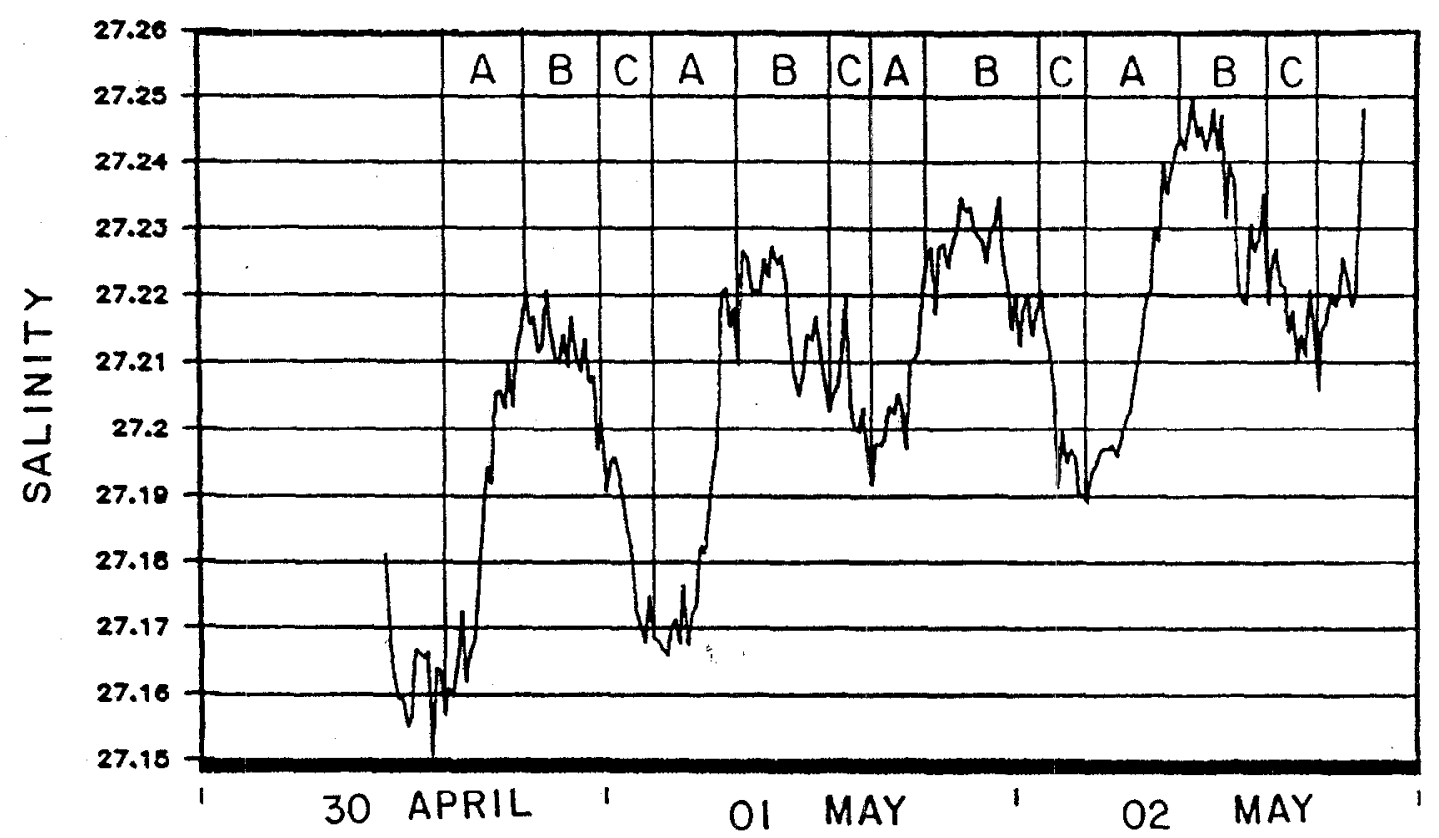

Figure 7b. Salinity fluctuations recorded at the interface, at station R, over four tidal cycles. The letters delimit the periods with stable current orientations (figure 7a).

\section{Salinity gradient}

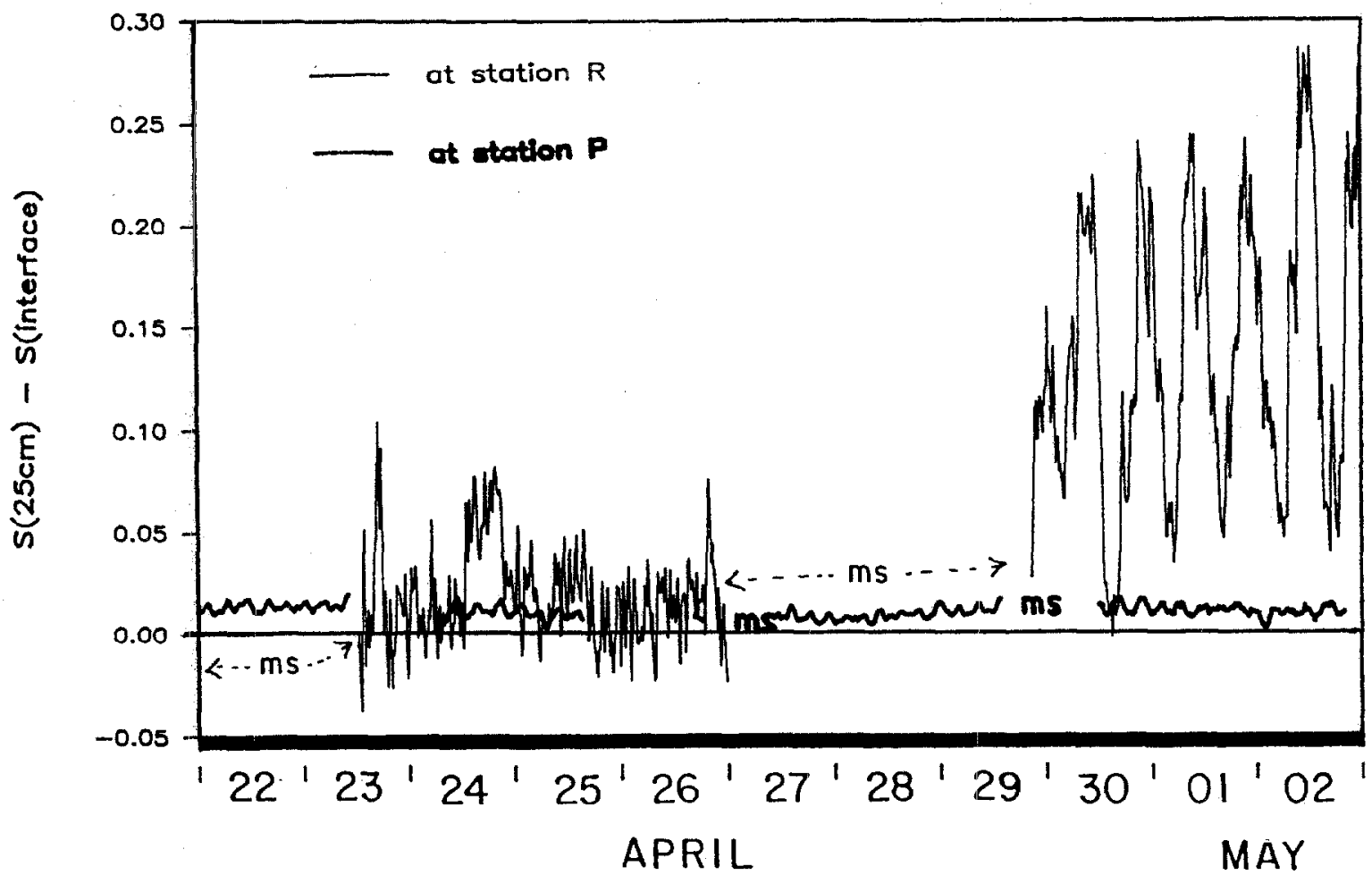

Figure 8. Salinity gradients $\left(\mathrm{S}_{25}-\mathrm{S}_{\text {interface }}\right.$ ) from a 2-h moving average calculated from data recorded at the interface and at $25 \mathrm{~cm}$ from the interface [ms indicates missing data]. 
phase at the $0+$ and $25 \mathrm{~cm}$ which indicates the periodic development and dissipation of a melt layer. Figure 8 compares gradient fluctuations calculated as the difference of salinity between our probes $\left(S_{25}-S_{\text {interface }}\right)$. It shows that maximum gradients are about twenty times higher in the vicinity of the ridge than in the centre of the plate. The fact that interface salinities at stations $R$ and $P$ are out of phase cannot be interpreted as proof of differential melting between these two locations. The dissipation of the melt layer on our recordings at station R shows clearly that in non-sheltered environments any trace of the melt layer may be erased. Moreover, the ice sheet becoming highly porous once the ice heat content increases, we could even consider a meltwater migration through the ice from deeper ice interfaces to the ones at a higher elevation.

However, these contrasted observations $75 \mathrm{~m}$ apart demonstrate a sheltering effect downstream of a ridge. This is confirmed by the plot of current direction against the time derivative of salinity at the interface over four tidal cycles beginning on 30 April at 18:00 (figure 9). This plot shows that salinity fluctuations and therefore the development and dissipation of a melt layer are strongly related to cur- rent orientation. We observe a clear decrease in salinity when the pressure ridge is upstream of our measurement site and, in contrast, an increase in salinity when our probes are upstream of the ridge. This opposition of phase demonstrates the periodic weakness of mixing processes in the vicinity of the ridge. In addition, the maximum current speed being about the same for both events, it may be assumed that away from the ridge influence mixing processes remained unchanged. Thus, when currents are oriented from the centre of the ice floe, station $R$ is in a non-sheltered environment; the temporal variability of mixing processes at station $\mathrm{R}$ also demonstrates a similar spatial variability of eddy diffusivity over the scale of an ice floe.

Based on these assumptions, data recorded at station $R$ during the two phases related to sheltered and nonsheltered conditions were used to run simulations in order to get an estimate of temporal and spatial eddy diffusivity variability.

During the three days showing the development of a melt layer, the opposition of phase between the interface and $25 \mathrm{~cm}$ below suggests that, when the meltwater layer develops, the upward flux of salt between these two

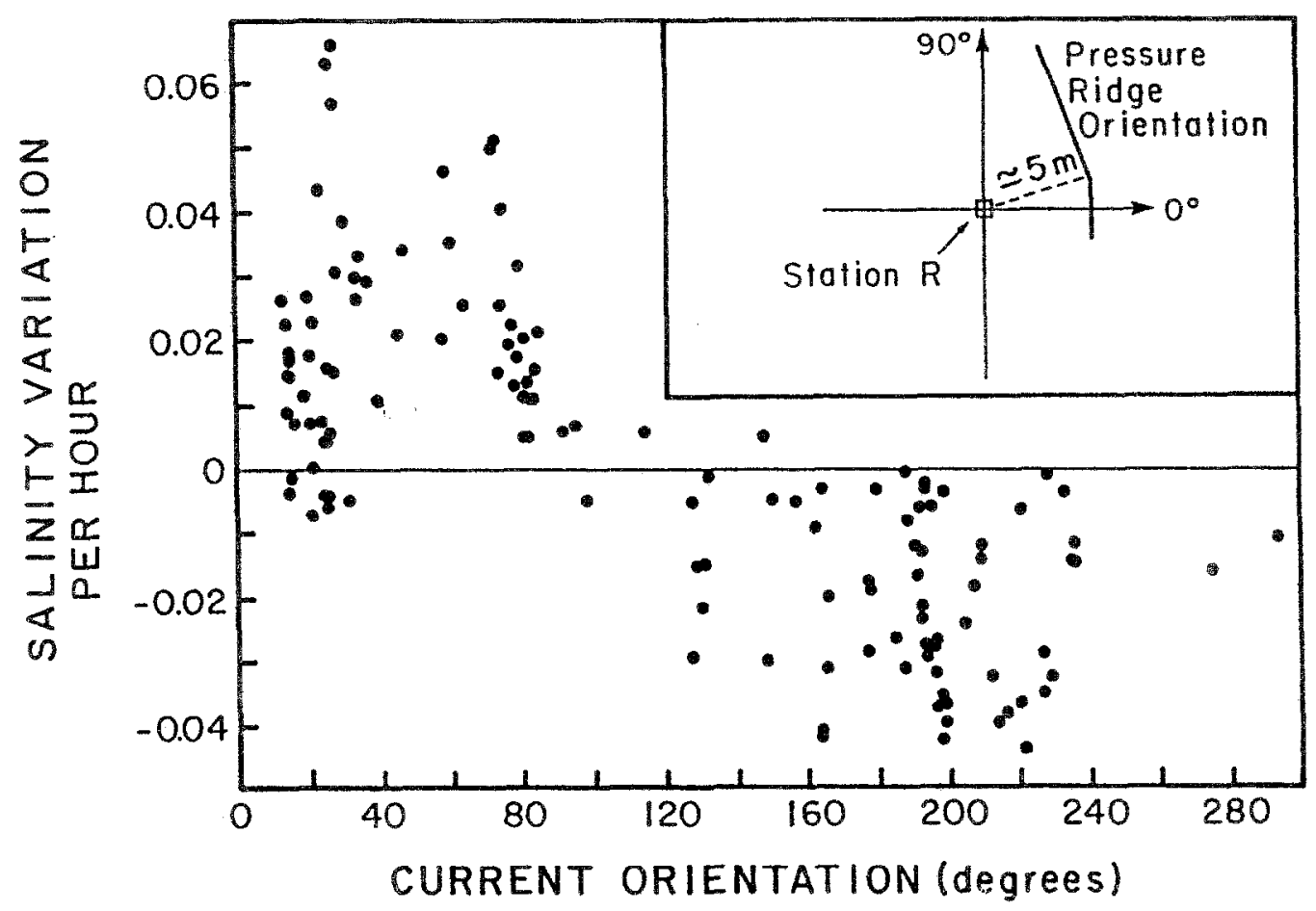

Figure 9. Plotting of $\partial \mathrm{S} / \partial \mathrm{t}$ calculated from data recorded at the interface vs. current direction measured at $2.5 \mathrm{~m}$ from the interface. Each dot results from a one-hour vector average beginning 30 April, at 18:00. 
probes may be negligible compared to the 'meltwater flux' $\left(F_{m 1}\right)$ :

$\mathrm{F}_{\mathrm{m}]} \gg(\alpha+\mathrm{K}) \partial \mathrm{S} / \partial \mathrm{z}$

Then using the basis equation for salt:

$\partial S / \partial t=\partial[(\alpha+K) \partial S / \partial z] / \partial z$

we obtain: $K \ll 4 \times 10^{-7} \mathrm{~m}^{2} \mathrm{~s}^{-1}$.

When station $\mathrm{R}$ is not sheltered, the increased mixing slowly dissipates the melt layer suggesting in turn an enhanced melt rate. It can then be assumed that the meltwater uptake $F_{m 2}$ is superior or equal to its value when mixing is at its minimum, $F_{m 2} \geq F_{m 1}$. Using equations (2), it follows: $\mathrm{K} \geq 3 \times 10^{-6} \mathrm{~m}^{2} \mathrm{~s}^{-1}$ (the two eddy diffusivity values give $\mathrm{K}$ between the two sensors).

Our simulations imply that a factor of 10 is a conservative evaluation of the spatial and temporal variability of eddy diffusivity under sea ice. Considering that ridges and rubble fields form a substantial fraction of ice-covered areas, it suggests that effects in their wake may be important in the global budget of ocean-ice exchanges.

\section{CONCLUSIONS}

The initiation of the melt on the underside of the ice was observed to start when the ice became isothermal. In addition, the development of a melt layer at the ice bottom was shown to occur when the snow layer became saturated with water, keeping the upward heat flux to a minimum. If confimmed, these observations could be of great importance in providing a simple way to determine the initiation of bottom icc mclt.

Our results show evidence of the periodic development and dissipation of a melt layer in the immediate vicinity of a pressure ridge while no similar observations were made away from the ridge. This phenomenon was, in addition, correlated with tidal current orientation, the melt layer being developed while our measurement site was downstream of the ridge and dissipated when currents turned and our station became upstream of the ridge. Away from pressure ridge influence, the upper boundary layer remained continuously well-mixed with maximum vertical salinity gradients less than $10 \%$ of those measured close to the ridge.

In this way, our results suggest a variability in the intensity of vertical exchanges with, in late spring, a minimum in the vicinity of ridges. It follows that depending on ridge height and density which typically ranges from 0.5 to 6.8 and up to 20 ridges $/ \mathrm{km}[3,19]$ the region where vertical exchanges are diminished could cover between 1 and $13 \%$ of the sea ice surface which, added to rubble fields, may represent up to $50 \%$ of the water-ice interface [18]. Although the observed consequence was, in late spring, a reduced upward flux, mainly caused by the buoyancy of the melt layer, in winter, on the contrary, the consequence may be an increase of the upward flux due to the eddy developing in the wake of the ridge.

Besides, the development of a stable melt layer downstream of a pressure ridge modifies the boundary layer charactcristics. In spring, this induces changes in the physical characteristics of the ice interface which in turn may modify the biomass estimations which were mostly made from data collected away from ridges.

\section{Acknowledgements}

The fieldwork relied heavily on the expertise of Paul Peltola and Claude Belanger. Funding for this project was obtained through the Natural Sciences and Engineering Research Council of Canada, Fonds FCAR (Quebec), and Fisheries and Oceans Canada.

\section{REFERENCES}

[1] Arya S.P.S., A drag partition theory for determining the largescale roughness parameter and wind stress on the arctic pack ice, J. Geophys. Res. 80 (1975) 3447-3454.

[2] Chriss T.M., Caldwell D.R., Evidence for the influence of form drag on bottom boundary layer flow, J. Geophys. Res. 87 (1982) 4148-4154.
[3] Gow A.J., Tucker III B.W., Sea ice in the polar region, in: Smith Jr W.O. (Ed.), Polar Oceanography, Part $\Lambda$, $\Lambda$ cademic Press, 1990, pp. 47-122.

[4] Hudier E.J-J., DeLisles D., Larouche Analyse de la distribution des crêtes de pression sur image satellitaire, Can. J. Rem. Sens. 19 (1993) 83i-87. 
[5] Ingram R.G., Larouche P., Variability of an under-ice river plume in Hudson Bay, J. Geophys. Res. 92 (1987) 9541-9547.

[6] Lewis E.L., Perkin R.G., Ice Pump and Their Rates, J. Geophys. Res. 91 (1986) 11756-11762.

[7] Lytle V.I., Ackley S.F., Sea ice ridging in the Eastern Weddell sea, J. Geophys. Res. 96 (1991) 18411-18416.

[8] Maykut G.A., Untersteiner N., Some results from a time dependent thermodynamic model of sea ice, J. Geophys. Res. 76 (1971) 1550-1575.

[9] Maykut G.A., The ice environment, in: Horner R.A. (Ed.), Sea Ice Biota, CRC Press, 1985, pp. 21-82.

[10] Maykut G.A., The surface heat and mass balance, in: Untersteiner N. (Ed.), The Geophysics of Sea Ice, The NATO ASI Ser., vol. B 146, Plenum Press, 1986, pp. 395-463.

[11] McPhee M.G., The upper ocean, in: Untersteiner N. (Ed.), The Geophysics of Sea Ice, Plenum Press, 1986, 339-394.

[12] McPhee M.G., Maykut G.A., Morison J.H., Dynamics and thermodynamics of the ice/upper ocean system in the marginal ice zone of the Greenland sea, J. Geophys. Res. 92 (1987) 7017-7031.

[13] Mellor G.L., McPhee M.G., Steele M., Ice-seawater turbulent boundary layer interaction with melting or freezing, J. Phys. Oceanogr. 16 (1986) 1829-1846.

[14] Omstedt A., Wettlaufer J.S., Ice growth and oceanic heat flux: Models and measurements, J. Geophys. Res. 97 (1992) 93839390.
[15] Rahm L., Svensson U., On the mass transfer properties of the benthic boundary layer with an application to oxygen fluxes, Neth. J. Sea Res. 24 (1989) 27-35.

[16] Steele M., Mellor G.L., McPhee M.G., Role of the molecular sublayer in the melting or freezing of sea ice, J. Phys. Oceanogr. 19 (1989) 139-147.

[17] Svensson U., Omstedt A., A mathematical model of the ocean boundary layer under drifting melting ice, J. Phys. Oceanogr. 20 (1990) 161-171.

[18] Wadhams P., Sea ice morphology and its measurments, Arctic Technology and Policy, Dyer I., C. (Ed.), Chryssostomidis, Hemisphere pub. Corp., Washington DC, 1984, 179-195.

[19] Wadhams P., Sea ice thickness distribution in the Greenland sea and Eurasian Basin May 1987, J. Geophys. Res. C4 (1992) $5331-5348$.

[20] Wadhams P., Davy T., On the spacing and draft distribution of pressure ridge keels, J. Geophys. Res. 91 (1986) 10697 10708.

[21] Weeks W.F., Ackley S.F., Govoni J., Sea ice ridging in the Ross sea, Antartica as compared with sites in the Arctic, J. Geophys. Res. 94 (1988) 4984-4988.

[22] Williams E.C., Swithinbank W.M., de Q. Robin G., A submarine study of Arctic pack ice, J. Glaciol. 15 (1975) 349-362.

[23] Yaglom A.M., Kader B.A., Heat and mass transfer between a rough wall and turbulent fluid flow at high Reynolds and Peclet numbers, J. Fluid Mech. 62 (1974) 601-623. 